\section{Commentary to "Chromogranin A: Biological Function and Clinical Utility in Neuroendocrine Tumor Disease"}

\section{TO THE EDITORS:}

We read with interest the study by Modlin et al., published online on March 9, 2010, and although overall we found it to be valid, ${ }^{1}$ we found an error. We refer to this assertion in the abstract: "Serum and plasma measurements are concordant." This is not true because they differ markedly. Chromogranin A (CgA) measured in plasma appears to be far higher than in serum. This is supported by information provided on the Web site of CIS Bio International (Gif-sur-Yvette, France), the producer of immunoradiometric assay and enzyme immunoassay kits.

In the Discussion, Modlin et al. are right when they note that there is strong positive linear relationship between plasma and serum CgA levels, but this does not mean that the results are concordant and that the measurements undertaken in either sample type can be related to the same cutoff value.

According to the information presented on CIS Bio International's Web site, the cutoff value for plasma $\mathrm{CgA}$ is approximately $150 \mathrm{ng} / \mathrm{mL}$, which is approximately $50 \%$ higher than for the serum samples. The same observation appears in Fig. 1 in the article of Woltering et al., ${ }^{2}$ which has been cited by Modlin et al. in relation to the discussed correlation between plasma and serum CgA levels. It is possible that Modlin et al. did not analyze this figure carefully enough; it shows that the serum $\mathrm{CgA}$ level of $100 \mathrm{ng} / \mathrm{mL}$ corresponds to $150 \mathrm{ng} / \mathrm{mL}$ plasma level.

A similar comparison of $\mathrm{CgA}$ measurements in serum and plasma samples obtained contemporaneously from the same people (volunteers and patients) was performed in our laboratory, and we can confirm that these differences are real. ${ }^{3}$

\section{Wojciech Jeske, MD, PhD, Piotr Glinicki, BS,} and Renata Kapuścińska, BS, PhD

Department of Endocrinology, Centre of Postgraduate Medical Education, Bielanski Hospital, Warsaw, Poland e-mail: jeske.wojciech@gmail.com

Published Online: 12 June 2010

(c) The Author(s) 2010. This article is published with open access at Springerlink.com

OPEN ACCESS This article is distributed under the terms of the Creative Commons Attribution Noncommercial License which permits any noncommercial use, distribution, and reproduction in any medium, provided the original author(s) and source are credited.

\section{REFERENCES}

1. Modlin IM, Gustafsson BI, Moss SF, et al. Chromogranin Abiological function and clinical utility in neuroendocrine tumor disease. Ann Surg Oncol. doi:1245/s10434-010-1006-3.

2. Woltering EA, Hilton RS, Zolfoghary ChM, et al. Validation of serum versus plasma measurements of chromogranin A levels in patients with carcinoid tumors. Lack of correlation between absolute chromogranin A levels and symptoms frequency. Pancreas 2006;33:250-4.

3. Glinicki P, Kapuścińska R, Jeske W. The difference in chromogranin A $(\mathrm{CgA})$ concentration measured in plasma and serum. Endokrynol Pol. 2010;61(2):241. 